\title{
Basal-Area Growth and Reproductive Responses of Thurber Needlegrass and Squirreltail to Weed Control and Nitrogen Fertilization
}

\author{
RICHARD E. ECKERT, JR., AND JOHN S. SPENCER
}

\begin{abstract}
Effects of weed control and added nitrogen were evaluated in terms of basal area growth, number of reproductive culms, seed yields, and test weight and germination of seed from individual plants of squirreltail (Sitanion hystrix) and Thurber needlegrass (Stipa thurberiana) from 1974 to 1979. Basal-area growth of Thurber needlegrass plants continued during the study period but at a reduced rate during dry years. Parts of squirreltail crowns died during dry periods. A reduction in competition by weed control and added nitrogen stimulated basal area growth of Thurber needlegrass, enhanced germination of squirreltail seed, and increased the number of reproductive culms and seed yield of both species, particularly in years of high precipitation. Germination of squirreltail was much greater than that of Thurber needlegrass. Results are discussed in relation to community ecology, range improvement practices, and seed production for commerce.
\end{abstract}

Herbage production by a bunchgrass stand is, in part, dependent on the number and size of plants. Various range improvement practices that control weeds and reduce intraspecific competition have been used to increase the density and size of desirable resident species. Practices such as control of brush and annual weeds can, at least temporarily, increase soil moisture and nitrogen available to residual plants (Hyder and Sneva 1956; Hedrick et al. 1966; Eckert and Evans 1967; Eckert et al. 1970, 1972). Information about the growth and reproductive characteristics of species can be used to predict possible responses of basal cover and plant density after vegetation manipulation.

In this study we evaluated the effects of weed control and nitrogen fertilization on basal area, on the number of reproductive culms, and seed production by individual plants of Thurber needlegrass (Stipa thurberiana) and squirreltail (Sitanion hystrix), and on test weight and germination of seed from these plants.

\section{Methods}

The study was conducted at Bedell Flat about $32 \mathrm{~km}$ north of Reno, Nev., on a site representative of the Wyoming big sagebrush/Thurber needlegrass (Artemisia tridentata ssp. wyomingensis)/(Stipa thurberiana) habitat type (Hironaka and Fosberg 1979). Soil is classified as a coarse-loamy, mixed mesic Mollic Haplargid. Sagebrush at this site was destroyed by a wildfire in the 1950's. When an exclosure was built in 1962, the

\footnotetext{
Authors are, respectively, range scientist and agricultural research technician. U.S Dep. Agr., Agr. Res. Serv. Renewable Resources Center, 920 Valley Road, University of Nevada. 89512 .

This research is the result of cooperative investigation of the U.S. Dep. Agr., Agr Kes. Serv., and the Agr. Exp. Sta., Univ. of Nevada, Reno, Nev. Journal Series No. 513.

Manuscript received April 13, 1981.
}

vegetation consisted of scattered plants (<1\% canopy cover) of big sagebrush with Thurber needlegrass, squirreltail and cheatgrass (Bromus tectorum) in the understory. Precipitation for October through June was: $22 \mathrm{~cm}$ in 1973-74; $25 \mathrm{~cm}$ in 1974-75; $11 \mathrm{~cm}$ in $1975-76 ; 11 \mathrm{~cm}$ in 1976-77; $24 \mathrm{~cm}$ in 1977-78; and $13 \mathrm{~cm}$ in 1978-79. On the average, $90 \%$ of the total annual precipitation falls during this period. About $6 \mathrm{~cm}$ of the total precipitation in 1976-77 occurred from April through June. In other years, precipitation for this period was less than $0.6 \mathrm{~cm}$.

Thirty plants (10 plants/treatment) of Thurber needlegrass and squirreltail were randomly selected in each of three replications in the fall of 1973. We used these sample plants to evaluate treatments throughout the study. Plants in the check treatment were subjected to severe competition from cheatgrass and other annual species. Previous work at this site showed that soil moisture under this condition was above -15 bars at $23 \mathrm{~cm}$ by the middle of May and about -9 bars at $46 \mathrm{~cm}$ by the end of June (Evans et al. 1970). In addition, $\mathrm{NO}_{3}-\mathrm{N}$ levels were low in the surface $30 \mathrm{~cm}$ of soil and averaged $4.5 \mathrm{~kg} /$ ha during the growing season (Eckert et al. 1970). Each year the weed control treatment was hoed to remove all herbaceous vegetation from a circular area of $0.22 \mathrm{~m}^{2}$ around each plant. Previous work showed that such a reduction in competition resulted in a soil moisture pattern of about -1 bar at $23 \mathrm{~cm}$ by the middle of May and less than -1 bar at $46 \mathrm{~cm}$ through the growing period. Also, weed control resulted in an average accumulation of $22.1 \mathrm{~kg} / \mathrm{ha}$ of $\mathrm{NO}_{3}-\mathrm{N}$ in the surface $30 \mathrm{~cm}$ of soil during the spring and ea rly summer through mineralization. The third treatment was weed control plus $45 \mathrm{~kg} / \mathrm{ha}$ nitrogen as urea applied in the fall of each year.

Reproductive culms were clipped and bagged when seed was mature, usually in the last week of June or the first week of July. Both species have an indeterminate type of reproductive maturity with seed at the top of the inflorescence ripening first. When ripe, seed of Thurber needlegrass easily disarticulates above the glumes and falls from the plant in response to a slight breeze. The rachis of squirreltail easily disarticulates at each node and entire sections of the inflorescence break from the plant in a gentle breeze. Even though we observed reproductive maturity carefully to select a sample date to minimize seed loss, an estimated $10 \%$ of the seed yield was lost before harvest and about $5 \%$ of the seed was immature. The number of reproductive culms per plant was counted in the laboratory. Seed was removed from the inflorescence, handprocessed to remove awns, and weighed.

Treatments were evaluated by measuring changes in basal area, the number of reproductive culms and seed yield $/ \mathrm{cm}^{2}$ of basal area of each plant, the test weight/ 100 seeds, and germination after 21 days. Number of culms and seed yield were evaluated on the basis of basal area because regression analysis showed a weak, but 
significant, positive relationship ( $r^{2}=20.5$ and $17.9 \%$, respectively) between these two parameters and basal area. Germination tests were conducted a constant $15^{\circ} \mathrm{C}$. This is the optimum temperature for squirreltail (Young and Evans 1977). No optimum germination temperature has been reported for Thurber needlegrass. Measurements were made in 1974 through 1979 except that number of culms was not detcrmined in 1974. Live and dead basal arca of each plant was calculated in 1974,1977 , and 1979 by the ellipse formula $(A=\pi a b)$. where $a$ and $b$ are the major and minor radii, respectively. Basal area measured in 1974 was used to calculate the number of culms and seed yield per unit of basal a rea for the 1974 and 1975 treatments. Because 1976 and 1977 were dry years, basal area from 1977 was used for treatment comparisons in those years. Basal area from 1979 was used to compare 1978 and 1979 treatments. Treatment means for basal area growth and reproductive characteristics were compared by Duncan's multiple range test at the $5 \%$ level of probability.

\section{Results and Discussion}

\section{Basal-Area Growth}

Environmental factors, such as precipitation, and treatments that influence available soil moisture and soil nitrogen would be expected to influence the size of established plants and thereby the number of vegetative and reproductive primordia. The basal area of individual grass plants averaged over all treatments was significantly larger in $1979\left(125 \mathrm{~cm}^{2}\right)$ than in 1974 and $1977(94$ and 90 $\mathrm{cm}^{2}$, respectively). Fach species, however, responded differently. Basal area of Thurber needlegrass increased from $68 \mathrm{~cm}^{2}$ in 1974 to $93 \mathrm{~cm}^{2}$ in 1977 , and to $140 \mathrm{~cm}^{2}$ in 1979 . Basal area of squirreltail decreased from $121 \mathrm{~cm}^{2}$ in 1974 to $85 \mathrm{~cm}^{2}$ in 1977 , then increased to $110 \mathrm{~cm}^{2}$ in 1979 .

The reduction in basal cover of squirreltail occurred after low precipitation in 1975-76 and 1976-77. During this period the amount of dead cover increased by $77 \%$. From 1976 to 1979 basal growth resumed, probably in response to the moist year of 1977-78, although measurements were not taken until 1979. During this period, the amount of dead basal area decreased by $33 \%$. Basal growth of Thurber needlegrass increased by $37 \%$ during the dry years and the amount of dead area increased by only $16 \%$. The amount of dead basal cover also increased an additional $11 \%$ from 1977 to 1979 . In spite of this, the large increase in live basal area by 1979 resulted in significantly larger Thurber needlegrass plants (140 $\left.\mathrm{cm}^{2}\right)$ than squirreltail plants $\left(110 \mathrm{~cm}^{2}\right)$, a reversal of the situation that existed at the start of the study.

The average basal cover of squirreltail plants ranged from 102 to
$110 \mathrm{~cm}^{2}$ with no significant difference among treatments. The average basal cover of Thurber needlegrass plants was significantly greater on the weed control and weed control plus nitrogen treatments (121 and $103 \mathrm{~cm}^{2}$, respectively) than on the check $\left(78 \mathrm{~cm}^{2}\right)$.

Results showed that basal area growth of squirreltail was more variable than that of Thurber needlegrass particularly in low precipitation years. Squirreltail is an increaser species in the sagebrush-grass region (Tisdale and Hironaka 1981). It reproduces well but is relatively short-lived (5-7 years) (Hironaka and Fosberg 1979). Perhaps older plants of this species in the stand were susceptible to dry conditions in 1976 and 1977 or plants of the species, in general, are not as well adapted to dry situations as are plants of the climax-dominant species, Thurber needlegrass. Results also show that the basal area of Thurber needlegrass can be increased by treatment. In practice, the most likely treatment would be one that reduces competition through the weed control rather than through additional nitrogen. An effective treatment should result in more ground cover for watershed stability, more vegetative primorida for initiation of vegetative culms and increased yield, and more reproductive primoridia for initiation of reproductive culms and increased seed production under favorable environmental conditions.

West et al. (1979) showed that community stability in a shrub /grass type appearently was achieved more by filling a competitive vacuum by change in basal area of resident grasses rather than by changes in age-class distribution. Plant density, however, did increase in years after a reduction in basal area. Hyder and Sneva (1956) also showed a $30 \%$ increase in the number of bunchgrass plants following sagebrush control. Therefore, in addition to changes in basal area, environmental factors or treatments that reduce competition or add nitrogen also may affect changes in the reproductive potential of resident grasses.

\section{Reproductive Characteristics}

The number of reproductive culms, seed yield, and test weight and germination of seed varied with year, species, and treatment (Table 1). The greatest number of reproductive culms and largest seed yield were produced in 1975 followed by 1974,1978 , and 1977 . No seed was produced in 1976 or 1979 . The small reproductive response in 1977 , in spite of the generally dry conditions, may have been the result of above average spring precipitation in that year. The small reproductive response in 1978 , in spite of generally wet conditions, may have been the result of a residual effect of the preceding two very dry years. Seed test weight was highest in 1974 and 1978 and lowest in 1975 and 1977. Germination was highest in 1978 , less in 1975 and 1977 , and least in 1974 . The average number

Table 1. Effects of weed control and nitrogen fertilization on number of reproductive culms, and on yield, test weight, and germination of squirreltail and Thurber needlegrass seed for 6 years.

\begin{tabular}{|c|c|c|c|c|}
\hline Experimental variable & $\begin{array}{l}\text { Reproductive culms (no } \\
\mathrm{cm}^{2} \text { basal area) }\end{array}$ & $\begin{array}{l}\text { Seed yield (mg/ } \mathrm{cm}^{2} \\
\text { basal area) }\end{array}$ & $\begin{array}{l}\text { Seed test weight } \\
(\mathrm{mg} / 100 \text { seeds })\end{array}$ & $\begin{array}{c}\text { Germination } \\
(\%)\end{array}$ \\
\hline $\begin{array}{c}\text { Year: } \\
1974 \\
1975 \\
1976 \\
1977 \\
1978 \\
1979\end{array}$ & $\begin{array}{l}-1 \\
1.9 \mathrm{a}^{2} \\
0.1 \mathrm{e} \\
0.4 \mathrm{c} \\
0.9 \mathrm{~b} \\
0.2 \mathrm{~d}\end{array}$ & $\begin{array}{r}45.2 \mathrm{~b} \\
67.4 \mathrm{a} \\
0.0 \mathrm{e} \\
4.5 \mathrm{~d} \\
17.7 \mathrm{c} \\
0.0 \mathrm{e}\end{array}$ & $\begin{array}{l}244 a \\
198 b \\
- \\
196 b \\
234 a \\
-\end{array}$ & $\begin{array}{l}37.4 \mathrm{c} \\
58.8 \mathrm{~b} \\
- \\
62.6 \mathrm{~b} \\
71.4 \mathrm{a} \\
-\end{array}$ \\
\hline $\begin{array}{l}\text { Species: } \\
\text { Squirreltail } \\
\text { Thurber needlegrass }\end{array}$ & $\begin{array}{l}0.6 \mathrm{a} \\
0.7 \mathrm{a}\end{array}$ & $\begin{array}{l}33.6 \mathrm{a} \\
33.8 \mathrm{a}\end{array}$ & $\begin{array}{l}19 l b \\
248 a\end{array}$ & $\begin{array}{l}83.6 \mathrm{a} \\
30.6 \mathrm{~b}\end{array}$ \\
\hline $\begin{array}{l}\text { Treatment: } \\
\text { Check } \\
\text { Weed control } \\
\text { Weed control plus nitrogen }\end{array}$ & $\begin{array}{l}0.5 \mathrm{~b} \\
0.6 \mathrm{~b} \\
0.9 \mathrm{a}\end{array}$ & $\begin{array}{l}24.6 \mathrm{~b} \\
32.2 \mathrm{~b} \\
44.3 \mathrm{a}\end{array}$ & $\begin{array}{l}216 a \\
204 a \\
207 a\end{array}$ & $\begin{array}{l}51.7 \mathrm{~b} \\
58.4 \mathrm{a} \\
58.5 \mathrm{a}\end{array}$ \\
\hline
\end{tabular}

INo data.

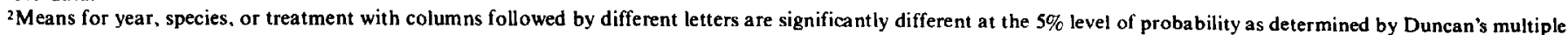
range test. 
of reproductive culms and seed yield $/ \mathrm{cm}^{2}$ of basal area were similar for squirreltail and Thurber needlegrass. Seed of Thurber needlegrass had a higher test weight ( 202 to $282 \mathrm{mg}$ ) than did squirreltail (170 to $212 \mathrm{mg}$ ) in cach year.

The treatment combination of weed control plus nitrogen resulted in more reproductive culms and a higher seed yield than did the other two treatments. This treatment was particularly effective in increasing the number of reproductive culms of Thurber needlegrass but did not increase seed yield. Both species produced seeds of similar test weight in all treatments. Germination of squirreltail seed in each treatment was greater than for Thurber needlegrass seed in comparable treatments. Germination of squirreltail seed from weed control and weed control plus nitrogen treatments ( 90 and $87 \%$, respectively) was higher than on the check (74\%). Germination of Thurber needlegrass seed (29 to 33\%) did not differ significantly among treatments. Sneva et al. (1958) found that nitrogen fertilization also increased the number of seed heads per plant, allowed normal seed maturation, and did not impair seed viability even in the driest year.

Average germination of Thurber needlegrass (29 to 33\%) was much lower than for squirreltail seed $(84 \%)$ in the present study and for native bunchgrasses such as bluebunch wheatgrass (Agropyron spicatum) (89\%), (Young et al. 1981); Idaho fescue (Festuca idahoensis) (77\%), (Young et al. 1981); and Sandberg bluegrass (Poa sandbergii) (86\%), (Evans et al. 1977). Is the low germination of Thurber needlegrass due to inherent characteristics of the species or to our inability to test the germinability of its seed? Young (unpublished results, Agricultural Research Service, Reno, NV) found that Thurber needlegrass seed collected yearly from 1973 to 1977 germinated from 7 to $70 \%$ at $15^{\circ} \mathrm{C}$. Germination of seed collected at four locations in 1975 ranged from 25 to $60 \%$ at $15^{\circ} \mathrm{C}$. Based on limited data, the optimum temperature for germination appears to be 15 or $20^{\circ} \mathrm{C}$. Young concluded that the "germinability of Thurber needlegrass seed is erratic and often quite low, and the nature of the dormancy controlling germination is unknown. Occasionally a dramatic enhancement in germination can be obtained by exposing imbibed seeds to red light filtered to exclude wavelengths longer than $760 \mathrm{~mm}$. Usually this enhancement cannot be duplicated in repeated experiments using seed from the same lot." Obviously much more research on the germination of this species is required before the question posed above can be answered.

\section{Application of Results}

Several of the interactions among experimental variables suggest useful information for management. Greatest crown growth, and most reproductive culms and highest seed weight $/ \mathrm{cm}^{2}$ of basal area occurred in the most favorable precipitation years and with the weed control plus nitrogen treatment. Therefore, range improvement practices designed to reduce competition should give the best response in wet years. For example, a sagebrush control project planned for late May could either be postponed or implemented on the basis of antecedent precipitation and soil moisture. In a high precipitation year, resident grass plants would be expected to produce more crown growth, more reproductive culms, and more germinable seed than if the brush control program were conducted in a dry year. Such planning would be particularly important in stands with a marginal density of desirable grasses. The objective would be to fill the environmental void created by weed control as rapidly as possible to prevent an increase in undesirable native or alien species (Young et al. 1969). Hopefully, after weed control in a sparse stand, we would find that the community plasticity described by West et al. (1979) would be controlled more by an increase in density of desirable species than by an increase in basal growth only. The environmental potential for soil moisture and soil nitrogen released by weed control would benefit germination of seed produced and also emergence and establishment of seedlings.

Seed weight/plant was converted to $\mathrm{kg} / \mathrm{ha}$ (based on $0.9 \mathrm{~m}$ between plants) in order to estimate seed production under field conditions, and potentially under cultivation. Yield of squirreltail seed ranged from 1 to $2 \mathrm{~kg} / \mathrm{ha}$ in the dry year of 1977 on all treatments, to 63 and $73 \mathrm{~kg} / \mathrm{ha}$ on the check and weed control treatments, respectively, and to $132 \mathrm{~kg} /$ ha on the weed control plus nitrogen treatment in the wet year of 1975 . Seed yield of Thurber needlegrass ranged from 6 to $9 \mathrm{~kg}$ / ha on all treatments in 1977, to $28 \mathrm{~kg} / \mathrm{ha}$ on the check, and 41 to $48 \mathrm{~kg} / \mathrm{ha}$ from treated plants in 1975. Seed of both species could be harvested in good precipitation years on sites with an adequate plant density and where weeds had been controlled. These yields would approximate those on the weed control treatment in this study. In the wettest year, seed yield of both species was increased by addition of nitrogen, but only squirreltail significantly so. The highest seed yield of squirreltail (11 g/plant) compares favorably with yield of crested wheatgrass (Agropyron desertorum) of $9 \mathrm{~g} /$ plant obtained in other study on similar sites (Eckert 1979). In comparison, the best seed yield of Thurber needlegrass was about $4 \mathrm{~g}$ /plant. Although a nitrogen treatment would likely not be used to increase seed production under dryland conditions, nitrogen with irrigation may increase seed production under cultivation. Standing brush, alive or dead, would interfere with machine harvesting; therefore, burning or some mechanical form of brush control would be necessary on some areas before seed could be collected.

Squirreltail seed is available commercially. The authors know of no commercial source of Thurber needlegrass seed. Results of this study have indicated seed yields that can be expected under field conditions and this may help native seed collectors determine the benefit/cost of field collection or perhaps of raising seed of this species under cultivation. A source of Thurber needlegrass seed would give the land manager the option of using a climaxdominant native species for reseeding the drier sagebrush communities where only crested wheatgrass has been used previously. Low seed germination, however, and very low seedling vigor (Hironaka and Fosberg 1979) of Thurber needlegrass could result in poor stands. For example, Wood et al. (1982) compared emergence and establishment of crested wheatgrass, squirreltail, and Thurber needlegrass. When the three grasses were planted at the rate of one seed $/ 1.3 \mathrm{~cm}$ of row, average emergence was, respectively, 21,18 , and $6 \%$ in a normal year and 8,6 , and $1 \%$ in a dry year. Average establishment of the three species was 68,62 , and $45 \%$ frequency per $30-\mathrm{cm}$ row in a normal year and 62,48 , and $3 \%$ frequency in a dry year. In addition, Thurber needlegrass is not as tolerant to grazing during the growing season as is crested wheatgrass.

Results obtained from the check treatment in this study would simulate the responses of a bunchgrass growing under intense competition from weedy species in a closed community (Robertson and Pearse 1945). Such a condition exists in a low-condition plant community containing a few palatable herbaceous species and a heavy cover of unpalatable shrubs or weedy annuals. In dry years, basal growth of grass would be slowed or crowns may actually disintegrate, and the reproductive capacity would be very low. In wet years, however, the potential for a reproductive response of both desirable and undesirable species increases. If basal growth does not respond rapidly enough to fill the competitive vacuum, space is available for seedlings of the most adapted species. This void may well be filled by seedlings of undesirable species, particularly on ranges in poor or fair ecological condition (unpublished research, Agriculture Research Service, Reno, NV). Low seed production, poor germination, and weak seedling vigor of Thurber needlegrass suggest reasons why range improvement through grazing management alone in a closed community will occur very slowly if at all.

\section{Literature Cited}

Eckert, R.E., Jr., and R.A. Evans. 1967. A chemical-fallow technique for control of downy brome and establishment of perennial grasses on rangeland. J. Range Manage. 20:35-4l. 
Eckert, R.E., Jr., G.J. Klomp, J.A. Young, and .R.A. Evans. 1970. Nitratenitrogen status of fallowed rangeland soils. J. Range Manage. 23:445447.

Eckert, R.E., Jr., A.D. Bruner, and G.J. Klomp. 1972. Response of understory species following herbicidal control of low sagebrush. J. Range Manage. 25:280-285.

Eckert, R.E., Jr. 1979. Renovation of sparse stands of crested wheatgrass. J. Range Manage. 32:332-336.

Evans, R.A., H.R. Holbo, R.E. Eckert, Jr., and J.A. Young. 1970. Functional environment of downy brome communities in relation to weed control and revegetation. Weed Sci. 18:154-162.

Evans, R.A., J.A. Young, and B.A. Roundy. 1977. Seedbed requirements for germination of Sandberg bluegrass. Agron. J. 69:817-820.

Hedrick, D.W., D.N. Hyder, F.A. Sneva, and C.E. Poulton. 1966. Ecological response of sagebrush-grass range in central Oregon to mechanical and chemical removal of Artemisia. Ecology 47:432-439.

Hyder, D.N., and F.A. Sneva. 1956. Herbage response to sagebrush spraying. J. Range Manage. 9:34-38.

Hironaka, M., and M.A. Fosberg. 1979. Non-forest habitat types of southern Idaho. Forest Wildl. and Range Exp. Sta., unnumbered Interim Report. Univ. of Idaho, Moscow. 208 p.

Robertson, J.H., and C.K. Pearse. 1945. Artificial reseeding and the closed community. Northwest Sci. 19:58-60.
Sneva, F.A., D.N. Hyder, and C.S. Cooper. 1958. The influence of ammonium nitrate on the growth and yield of crested wheatgrass on the Oregon High Desert. Agron. J. 50:40-44.

Tisdale, E.W., and M. Hironaka. 1981. The sagebrush-grass region: A review of the ecological literature. Forest, Wildl. and Range Exp. Sta., Bull No. 33. Univ. of Idaho, Moscow. 31 p.

West, N.E., K.H. Rea, and R.O. Harniss. 1979. Plant demographic studies in sagebrush-grass communities in southeastern Idaho. Ecology 60:376388.

Wood, M.K., R.E. Eckert, Jr., W.H. Blackburn, and F.F. Peterson. 1982. Influence of crusting soil surfaces on emergence and establishment of crested wheatgrass, squirreltail, Thurber needlegrass, and fourwing saltbush, J. Range Manage. 35:282-287.

Young, J.A., R.A. Evans, and R.E. Eckert, Jr. 1969. Population dynamics of downy brome. Weed Sci. 17:20-26.

Young, J.A., and R.A. Evans. 1977. Squirreltail seed germination. J. Range Manage. 30:33-36.

Young, J.A., R.E. Eckert, Jr., and R.A. Evans. 1981. Temperature profiles for germination of bluebunch and beardless wheatgrasses. J. Range Manage. 34:84-89.

Young, J.A., R.A. Evans, R.E. Eckert, Jr., and R.D. Ensign. 1981. Germination-temperature profiles for Idaho and sheep fescue and Canby bluegrass. Agron. J. 73:716-720.

CHANGE OF ADDRESS notices should be sent to the Managing Editor, 2760 West Fifth Ave., Denver, Colo. 80204, no later than the first day of the month of issue. Copies lost due to change of address cannot be replaced unless adequate notice is given. To assure uninterrupted service, provide your local postmaster with a Change of Address Order (POD Form 3575) indicating thereon to guarantee forwarding postage for second-class mail. 